Jurnal Agro 8(1), 2021

\title{
RESPONS TANAMAN PADI (Oryza sativa L.) TERHADAP SISTEM TANAM DAN JUMLAH BIBIT PER LUBANG TANAM
}

\section{RESPONSE OF LOWLAND RICE (Oryza sativa L.) TO CROPPING SYSTEM AND SEED NUMBER PER PLANTING HOLE}

\author{
Ndari Retno Lestari, Soni Isnaini*, Safiuddin, Yatmin, Maryati \\ Sekolah Tinggi Ilmu Pertanian (STIPER) DHARMA WACANA METRO \\ Jl. Kenanga \#3 Mulyojati 16C Kota Metro \\ *Koresponding Penulis sonisnaini@yahoo.co.id
}

Diterima : 19 Desember 2020 /Disetujui : 3 Mei 2021

\begin{abstract}
ABSTRAK
Sistem tanam (ST) yang sering digunakan petani yaitu ST tegel. Sampai sekarang masih banyak petani yang menggunakan bibit lebih dari tujuh batang per lubang tanam (BpLT). Tujuan penelitian adalah untuk mempelajari respon tanaman padi terhadap ST dan jumlah bibit per lubang tanam (JBpLT). Penelitian dilakukan di Desa Raman Aji, Kecamatan Raman Utara, Lampung Timur pada bulan Februari sampai Mei 2016. Perlakuan disusun dalam Rancangan Kelompok Teracak Lengkap dengan pola split plot. Petak utama adalah ST jarwo 2:1, ST Jarwo 4:1, dan ST tegel $25 \times 25 \mathrm{~cm}$. Anak petak terdiri atas JBpLT: 1 BpLT, 2 BpLT, dan 3 BpLT. Data dianalisis ragam dan dilanjutkan uji orthogonal kontras, semua pengujian dilakukan pada taraf 5\%. Hasil percobaan menunjukkan bahwa (1) ST jarwo 2:1 dan ST jarwo 4:1 meningkatkan pertumbuhan padi hibrida Mapan P-05 dibandingkan ST tegel $25 \times 25 \mathrm{~cm}$, (2) penanaman $1 \mathrm{BpLT}$ meningkatkan komponen hasil padi dibandingkan penanaman $2 \mathrm{BpLT}$ dan $3 \mathrm{BpLT}$, dan (3) penanaman $1 \mathrm{BpLT}$ memberikan hasil GKG $\left(6,86 \mathrm{t} \mathrm{ha}^{-1}\right)$ yang lebih tinggi dari penanaman $2 \mathrm{BpLT}$ $\left(5,64 \mathrm{t} \mathrm{ha}^{-1}\right)$ dan $3 \mathrm{BpLT}\left(4,59 \mathrm{t} \mathrm{ha}^{-1}\right)$ pada ST jarwo 2:1, ST jarwo 4:1 dan ST tegel $25 \times 25 \mathrm{~cm}$, secara berurutan.
\end{abstract}

Kata kunci: Bibit padi, Padi sawah, Sistem tanam

\begin{abstract}
The common planting system (PS) used by the farmers is Tegel system. Yet, many farmers still use more than seven seeds per planting hole $(\mathrm{SpPH})$. The research objective was to study the reponse of rice plants to the planting system and the number SpPH. The research was conducted in Raman Aji Village, Raman Utara, East Lampung from February to May 2016. The treatments were arranged in a RCBD with a split plot pattern (the main plot were the PS i.e. jarwo 2: 1, jarwo 4: 1 and "Tegel" $25 \times 25 \mathrm{~cm}$; the subplots are the number of SpPH i.e. $1 \mathrm{SpPH}$, $2 \mathrm{SpPH}$, and $3 \mathrm{SpPH}$ ). The results showed that (1) the jarwo 2: 1 system increased rice growth compared to the $25 \times 25 \mathrm{~cm}$ "Tegel"; (2) application of $1 \mathrm{SpPH}$ increased the yield component of rice compared to planting $2 \mathrm{SpPH}$ and SpPH; and (3) application of $1 \mathrm{SpPH}\left(6.86 \mathrm{t} \mathrm{ha}^{-1}\right)$ gave the higher weight of milled grain than using $2 \mathrm{SpPH}\left(5.64 \mathrm{t} \mathrm{ha}^{-1}\right)$ and $3 \mathrm{SpPH}\left(4.59 \mathrm{t} \mathrm{ha}^{-1}\right)$, both planted in the jarwo 2:1, jarwo 4:1 and $25 \times 25 \mathrm{~cm}$ "Tegel" System.
\end{abstract}

Cite this as: Lestari N R., Isnaini S., Safiuddin., Yatmin. \& Maryati. (2021). Respon tanaman padi (Oryza sativa L.) terhadap sistem tanam dan jumlah bibit. Jurnal Agro, 8(1), 153-163. https://doi.org/10.15575/10629 
Key word: Lowland rice, Rice seed, Planting system

\section{PENDAHULUAN}

Sistem tanam padi sawah sampai saat ini umumnya dilakukan petani menggunakan sistem tanam pindah (tapin). Sistem ini tidak banyak membutuhkan persyaratan khusus juga tidak banyak resiko, tetapi umumnya petani menanam bibit padi dalam jumlah yang banyak. Sampai sekarang, masih banyak petani yang menanamkan bibit dengan jumlah sekitar 3 -7 batang per lubang tanam (BpLT), bahkan ada yang lebih dari itu. Rekomendasi yang umum untuk penggunaan jumlah bibit padi sawah adalah 2-3 BpLT. Bahkan pada teknologi SRI (The Sistem of Rice Intensification), jumlah bibit yang diterapkan adalah 1 BpLT (Stoopet al., 2002; Uphoff, 2003; Thakuret al., 2010). Padi yang ditanam 1 BpLT akan menumbuhkan tunas, sehingga menghasilkan jumlah anakan yang lebih banyak, serta menghindari terjadinya kompetisi antar-anakan dalam satu rumpun (Kumalasari et al., 2017; Simangunsong et al., 2018).

Hasil penelitian Susilo et al. (2015) bahwasanya hasil ganah tertinggi sebesar 4,39 $\mathrm{t} \mathrm{ha}^{-1}$ gabah kering panen (GKP) diperoleh dari penanaman $1 \mathrm{BpLT}$ dengan jarak tanam $30 \mathrm{~cm} \times 30 \mathrm{~cm}$. Di pihak lain Wangiyana et al. (2009) melaporkan bahwa penanaman 2 BpLT menghasilkan komponen hasil dan hasil padi terbaik. Misran (2014) menyarankan untuk menghemat pemakaian benih disarankan penanaman bibit tidak lebih dari $3 \mathrm{BpLT}$, temuan yang sama dilaporkanAli et al. (2017).

Hasil yang berbeda dengan temuan di atas telah dilaporkan Arnama (2020) bahwasanya varietas Mekongga yang ditanam 2 BpLT lebih rendah hasil gabahnya dibandingkan yang ditanam 6 BpLT. Jumlah bibit per lubang tanam berpengaruh nyata terhadap hasil ubinan tanaman padi, jumlah bibit per rumpun yang baik adalah $1 \mathrm{BpLT}$ atau $2 \mathrm{BpLT}$ dengan hasil gabah antara 7,87 - 8,09 t ha ${ }^{-1}$ (Muyassir, 2012). Jumlah bibit yang relative lebih banyak yaitu $5-10 \mathrm{BpLT}$, bahkan >10 BpLT menyebabkan terjadinya persaingan sesama tanaman padi (kompetisi inter spesies) yang sangat keras untuk mendapatkan air, unsur hara, $\mathrm{CO}_{2}, \mathrm{O}_{2}$, cahaya, dan ruang untuk tumbuh sehingga pertumbuhan akan menjadi tidak normal. Penanaman bibit padi yang lebih sedikit (1 $3 \mathrm{BpLT}$ ), maka benih yang digunakan pun lebih sedikit, sehingga mengurangi biaya produksi. Menurut Yoshida (1981), kapasitas pembentukan anakan berkaitan dengan kemampuan tanaman padi menggunakan ruang pada sistem lahan sawah.

Penggunaan ruang pada sistem budidaya padi sawah, berkaitan langsung dengan teknologi budidaya padi itu sendiri, antara lain budidaya sistem tanam benih langsung (Tabela), maupun sistem tanam jarwo. Pengenalan dan penggunaan sistem tanam tersebut disamping untuk mendapatkan pertumbuhan tanaman yang optimal juga ditujukan untuk meningkatkan hasil gabah dan pendapatan petani. Pada umumnya petani sekarang masih menggunakan sistem tanam tegel; sistem tanam ini menggunakan jarak tanam yang lebar yaitu $(25 \times 25 \mathrm{~cm})$ atau $(30 \times 30 \mathrm{~cm})$. Hasil penelitian Donggulo et al. (2017) menunjukkan bahwa pengaturan jarak tanam padi yang memberikan hasil terbaik 
adalah jarak tanam $25 \times 25 \mathrm{~cm}$ dan sistem tanam jarwo.

Menurut Ikhwani et al. (2015), sistem tanam jarwo adalah cara tanam padi sawah yang memiliki beberapa barisan tanaman kemudian diselingi oleh 1 baris kosong dimana jarak tanam pada barisan pinggir $1 / 2$ kali jarak tanaman pada baris tengah. Cara tanam jarwo untuk padi sawah secara umum biasa dilakukan dengan berbagai tipe yaitu: jarwo (2:1), (3:1), (4:1), (5:1), (6:1) atau tipe jarwo lainnya. Simangunsong et al. (2018) melaporkan bahwa produksi padi tertinggi dihasilkan pada sistem tanam jarwo dengan jarak tanam $20 \times 20 \mathrm{~cm}$ populasi tanaman 60 rumpun per plot. Sistem tanam jarwo 2:1 adalah terbaik bagi pertumbuhan dan hasil padi sawah yang ditunjukkan dengan jumlah anakan total sebesar 28,48 batang, jumlah anakan produktif sebesar 25 batang dan bobot GKG

\section{BAHAN DAN METODE}

Penelitian dilakukan pada lahan persawahan Desa Raman Aji, Kecamatan Raman Utara, kabupaten Lampung Timur dengan jenis tanah Ultisols, tekstur tanah liat berpasir, kemiringan $0^{\circ}-15^{\circ}$, serta $\mathrm{pH}$ 4,5 - 6. Penelitian dilaksanakan pada bulan Februari sampai Mei 2016. Bahan yang digunakan pada penelitian ini berupa benih padi hibrida Mapan P-05, Urea (125 kg ha-1) yang dibeli di kios saprodi desa Raman Aji, NPK-Phonska (150 kg ha $\left.{ }^{-1}\right)$, dan pupuk organik $1 \mathrm{t} \mathrm{ha}^{-1}$ (kotoran ayam petelur).

Perlakuan disusun dalam perancangan lingkungan Rancangan Kelompok Teracak Lengkap (RKTL) yang perancangan perlakuannya berpola Split Plot. Sebagai petak utama adalah sistem tanam (J) yang terdiri atas: jarwo 2:1 $\left(\mathrm{j}_{1}\right)$, jarwo 4:1 $\left(\mathrm{j}_{2}\right)$ dan sistem tanam tegel $25 \times 25 \mathrm{~cm}\left(\mathrm{j}_{3}\right)$. Sebagai sebesar 66,16 g per rumpun serta selisih hasil GKG per petak 50,43 \% (Sari et al., 2014). Interaksi antara jumlah bibit per lubang tanam dan populasi tanaman secara nyata meningkatkan pertumbuhan tinggi tanaman tetapi tidak nyata meningkatkan hasil tanaman padi sawah. Kombinasi asam humat, jarak tanam $30 \times 30 \mathrm{~cm}$, dan $1 \mathrm{BpLT}$ merupakan perlakuan kombinasi terbaik terhadap pertumbuhan dan hasil tanaman padi 'Pandan Puteri' (Dani, 2018).

Berdasarkan permasalahan yang telah dipaparkan, maka perlu dilakukan kajian lebih mendalam untuk peningkatan produksi padi terhadap sistem tanam dengan jumlah bibit per lubang tanam yang tepat. Tujuan penelitian adalah untuk mempelajari respons tanaman padi terhadap sistem tanam dan jumlah bibit per lubang tanam.

anak petak adalah jumlah bibit per lubang tanam (U) yang terdiri atas: jumlah bibit $1 \operatorname{BpLT}\left(u_{1}\right), 2 \operatorname{BpLT}\left(u_{2}\right)$, dan $3 \operatorname{BpLT}\left(u_{3}\right)$. Kombinasi perlakuan diulang sebanyak 3 kali. Data diuji homogenitasnya dengan uji Bartlet dan ketidakaditifan data antara lingkungan dan perlakuan diuji dengan uji Tuckey. Kemudian data dianalisis ragam dan dilanjutkan dengan uji ortogonal kontras, semua pengujian dilakukan pada taraf 5\%.

Persiapan lahan percobaan meliputi pembuatan petakan percobaan yang berukuran $3 \mathrm{~m} \times 3 \mathrm{~m}$ dan pemasangan papan nama perlakuan. Pengolahan tanah sawah dilakukan dengan pembajakan yang dilakukan dengan menggunakan handtraktor. Setelah pembajakan, lahan digenangi air yang bertujuan agar homogenasi hasil pelumpuran mencapai maksimal, selain itu agar proses 
pembusukan serasah dan gulma yang ada lebih cepat.

Benih yang digunakan diseleksi terlebih dahulu sebelum disemaikan. Benih diseleksi dengan cara ditampi, direndam dengan air garam. Benih yang mengapung dibuang dan benih yang tenggelam dicuci dengan air bersih kemudian direndam selama 24 jam dalam air bersih lalu ditiriskan dan diperam selama 24 jam. Benih disemaikan dalam nampan dengan media tanah dan pupuk organik 1:1.

Sebelum dilakukan penanaman, air yang ada di petak percobaan dikeluarkan, kemudian petak percobaan digarit dengan caplak untuk cara tanam tegel $25 \times 25 \mathrm{~cm}$. Cara tanam jarwo sama seperti cara tanam tegel tetapi digarit dengan caplak dengan jarak tanam $25 \times 25 \mathrm{~cm}$ lalu ada lorong antar-baris selebar $50 \mathrm{~cm}$, kemudian setiap baris tanaman ke-1 dan ke-4 ditambahkan bibit dengan jarak tanam setengah dari jarak tanam antar-barisan untuk jarwo 4:1 dan cara tanam jarwo 2:1 sama dengan cara tanam jarwo 4:1 yaitu penambahan bibit dengan jarak tanam setengah dari jarak tanam antar-barisan pada baris ke-1 dan ke-

2. Bibit padi ditanam sesuai dengan perlakuan yang telah ditentukan antara petakan satu ke petakan berikutnya dengan sistem tanam dan jumlah bibit yang berbeda sesuai perlakuan.

Pemupukan urea dan NPK Phonska dilakukan 2 kali, sedangkan pupuk kandang dilakukan bersamaan saat pengolahan tanah dengan dosis $1 \mathrm{t} \mathrm{ha}^{-1}$ (50 kg petak ${ }^{-1}$ ). Pemupukan pertama dilakukan pada 5 hari setelah tanam (HST) dengan dosis pemupukan urea $75 \mathrm{~kg} \mathrm{ha}^{-1}\left(2,5 \mathrm{~kg}\right.$ petak $\left.^{-1}\right)$ dan NPK Phonska $75 \mathrm{~kg} \mathrm{ha}^{-1}\left(2,5 \mathrm{~kg}^{2}\right.$ petak $\left.{ }^{1}\right)$. Pemupukan kedua dilakukan pada waktu 15 HST, yaitu pemupukan urea $50 \mathrm{~kg} \mathrm{ha}^{-1}$ $\left(1,7 \mathrm{~kg}\right.$ petak $\left.^{-1}\right)$ dan NPK Phonska $75 \mathrm{~kg} \mathrm{ha}^{-1}$ $\left(2,5 \mathrm{~kg}\right.$ petak $\left.^{-1}\right)$. Acuan dan tata laksana pemupukan mengacu pada Buku PTT Padi Sawah Irigasi (Suyamto, 2007). Kondisi air pada lahan sawah saat pemupukan dibiarkan macak-macak.

Tanaman padi yang mati, karena dimakan hama keong emas dan mati karena putus akarnya saat pemindahan bibit dilakukan penyulaman pada saat tanaman berumur 7 HST dengan masing-masing jumlah bibit sesuai perlakuan. Penyiangan dengan mencabut gulma mulai pada saat tanaman padi berumur 10 HST. Tanaman padi yang diserang hama walang sangit saat pengisian malai disemprot insektisida Mipcindo 50 WP.

Pengamatan dilakukan dengan mengambil 10 rumpun sampel per petak, yang diambil secara acak dari populasi tanaman pada setiap petaknya, yaitu tinggi tanaman, laju tumbuh tanaman rata-rata 10 harian, nisbah pupus akar (NPA), jumlah anakan maksimum, jumlah anakan produktif, jumlah gabah per malai, persentase gabah isi per malai, bobot 1000 butir gabah isi, dan bobot gabah kering giling (GKG) ( $\mathrm{t} \mathrm{ha}^{-1}$ ).

\section{HASIL DAN PEMBAHASAN}

Jumlah gabah per malai, persentase gabah isi dan hasil gabah GKG dipengaruhi secara nyata oleh efek interaksi antara cara tanaman dan jumlah bibit per lubang tanam (Tabel 1). Hasil uji lanjutan terlihat bahwa kenaikan atau penurunan jumlah gabah per malai maupun persentase gabah isi sangat kecil (Tabel 2), tetapi nilai ini sudah cukup untuk menjelaskan efek interaksi dari kedua faktor perlakuan. Fakta ini dapat dijelaskan bahwa jumlah gabah per malai meningkat lebih dari $100 \%$ pada sistem tanam jarwo 4:1 dibandingkan sistem tanam tegel 
dengan penanaman bibit $1 \mathrm{BpLT}$ dan $2 \mathrm{BpLT}$, sedangkan pada 3 BpLT kenaikannya hanya mencapai $73 \%$. Hal ini berarti sistem tanam jarwo 4:1 mampu menghasilkan pembuahan bunga yang optimal. Faktor yang mendukung situasi ini adalah adanya cahaya yang mudah masuk diantara ruang kosong (legowo) setiap 4 baris tanaman, dan juga aliran udara/angin yang mengalir di ruang tersebut cukup untuk mendukung pembuahan bunga padi. Menurut Widyastuti et al. (2015), faktor lingkungan mempengaruhi penyerbukan padi adalah temperatur, kelembaban relatif, intensitas cahaya, dan kecepatan angin.

Jumlah gabah per malai yang diperoleh dari penanaman bibit $1 \mathrm{BpLT}$ lebih banyak daripada penanaman bibit 2 BpLT dan 3 BpLT pada ketiga cara tanam. Fakta yang serupa ditemukan pada penanaman bibit 2 BpLT lebih banyak menghasilkan jumlah gabah per malai dibandingkan penanaman bibit 3 BpLT, secara konsisten sistem tanam jarwo 2:1 lebih tinggi daripada jarwo 4:1 dan sistem tanam tegel. Temuan Safitri dan Suminarti (2018) memperlihatkan bahwa penanaman 1 BpLT menghasilkan bobot gabah per malai lebih tinggi $16 \%$ daripada penanaman 2 BpLT. Hal ini berhubungan dengan iklim mikro (intensitas cahaya matahari) yang mereka amati, ternyata dengan penanaman $3 \mathrm{BpLT}$ intensitas cahaya matahari relatif lebih rendah daripada 1 BpLT dan 2 BpLT.

Hasil GKG yang dihasilkan dengan cara tanam jarwo 2:1 lebih tinggi daripada jarwo 4:1 dan tegel pada ketiga jumlah bibit yang ditanam. Fakta yang sama diperoleh dari cara tanam jarwo 4:1 dibandingkan sistem tegel. Hasil GKG pada penanaman $1 \mathrm{BpLT}$ lebih tinggi $25 \%$ dan $59 \%$ daripada penanaman 2 BpLT dan $3 \mathrm{BpLT}$, secara berurutan. Sedangkan hasil GKG dengan cara tanam jarwo 4:1 lebih tinggi daripada tegel dengan penanaman 1 BpLT meningkatkan hasil GKG 40\% dibandingkan penanaman 2 BpLT. Di pihak lain, penanaman bibit $1 \mathrm{BpLT}$ lebih tinggi hasil GKG daripada 2 BpLT maupun 3 BpLT, begitu pula antara 2 BpLTdengan $3 \mathrm{BpLT}$ pada ketiga sistem tanam. Cara tanam jarwo 2:1 meningkatkan hasil GKG daripada jarwo 4:1 dan tegel masing-masing meningkat $43 \%$ dan $65 \%$. Temuan ini menunjukkan bahwa sistem tanaman dan jumlah bibit yang ditanam saling berinteraksi.

Tabel 1 menunjukkan efek interaksi dari peubah jumlah gabah per malai, persentase gabah isi dan hasil GKG, dan persentase kenaikan dari ketiga peubah dideskripsikan pada Tabel 2. Secara konsisten bahwa cara tanam jarwo 2:1 lebih baik daripada jarwo 4:1 dan tegel, dan jarwo 4:1 lebih baik daripada sistem tegel. Hal ini menunjukkan bahwa sistem tanaman jarwo, baik jarwo 2:1 maupun jarwo 4:1 mampu meningkatkan pertumbuhan dan perkembangan tanaman padi. Penambahan ruang kosong atau legowo mampu menyediakan ruang bagi berkembangnya tanaman padi, sehingga dua dari keempat komponen hasil yang diamati memberikan efek yang nyata.

Teknologi jarwo merupakan rekayasa teknik tanam dengan mengatur jarak tanam antar rumpun dan antar barisan sehingga terjadi pemadatan rumpun padi dalam barisan dan melebar jarak antar barisan sehingga seolah-olah rumpun padi berada di barisan pinggir dari pertanaman yang memperoleh manfaat sebagai tanaman pinggir (border effect). 
Tabel 1. Nilai F-hitung uji orthogonal kontras peubah tinggi tanaman, laju tumbuh tanaman (TT), nisbah pupus akar (NPA) 35 HST, jumlah anakan maksimum (JAM), jumlah malai, jumlah gabah (JG) per malai, persentase gabah isi, bobot 1.000 butir benih, dan hasil GKG padi yang ditanam pada berbagai cara tanam dan jumlah bibit per lubang tanam

\begin{tabular}{|c|c|c|c|c|c|c|c|c|c|c|c|}
\hline & Kontras & $\begin{array}{l}\text { Tinggi Tanaman } \\
50 \text { HST }\end{array}$ & LajuTT & $\begin{array}{c}\text { NPA } \\
35 \text { HST }\end{array}$ & JAM & $\begin{array}{c}\text { JumlahMala } \\
\mathbf{i}\end{array}$ & $\begin{array}{l}\text { JG per } \\
\text { Malai }\end{array}$ & $\begin{array}{l}\text { Persentase } \\
\text { Gabah Isi }\end{array}$ & $\begin{array}{c}\text { Bobot } 1.000 \\
\text { ButirBenih }\end{array}$ & Hasil GKG & $F-0,05$ \\
\hline \multicolumn{12}{|c|}{ A. Pengaruh Utama J dan U } \\
\hline & 1. $\mathrm{j}_{1} \mathrm{vs} . \mathrm{j}_{2} \mathrm{j}_{3}$ & $<1$ & $480,91^{*}$ & $1,13^{\text {tn }}$ & $<1$ & $1,57^{\mathrm{tn}}$ & $<1$ & $<1$ & $<1$ & $17,02^{*}$ & 7,71 \\
\hline & 2. $\mathrm{j}_{2} \mathrm{vs} . \mathrm{j}_{3}$ & $<1$ & $1320,00^{*}$ & $1,27^{\mathrm{tn}}$ & $21,32^{*}$ & $9,92^{*}$ & $2,94^{\text {tn }}$ & $8,89 *$ & $2,09^{\text {tn }}$ & $3,64^{\operatorname{tn}}$ & 7,71 \\
\hline & 3. $\mathrm{u}_{1}$ vs. $\mathrm{u}_{2} \mathrm{u}_{3}$ & $107,88^{*}$ & $<1$ & $4,98^{\operatorname{tn}}$ & $67,10^{*}$ & $41,64 *$ & $39,26^{*}$ & $389,70^{*}$ & $21,62^{*}$ & $158,86^{*}$ & 7,71 \\
\hline & 4. $u_{2}$ vs. $u_{3}$ & $39,79 *$ & $<1$ & $1,75^{\text {tn }}$ & $49,89^{*}$ & $22,88^{*}$ & $25,97^{*}$ & $62,26^{*}$ & $9,15^{*}$ & $52,10^{*}$ & 7,71 \\
\hline \multicolumn{12}{|c|}{ B. Pengaruh InteraksiJ $x^{\ddagger} U^{\ddagger}$} \\
\hline & 5. $\left(\mathrm{j}_{1}\right.$ vs. $\left.\mathrm{j}_{2} \mathrm{j}_{3}\right) \times\left(\mathrm{u}_{1}\right.$ vs. $\left.\mathrm{u}_{2} \mathrm{u}_{3}\right)$ & $<1$ & $2,17^{\mathrm{tn}}$ & $<1$ & $1,41^{\text {tn }}$ & $<1$ & $1,32^{\mathrm{tn}}$ & $46,92 *$ & $1,70^{\mathrm{tn}}$ & $58,85^{*}$ & 4,75 \\
\hline & 6. $\left(j_{1} v s . j_{2} j_{3}\right) \times\left(u_{2} v s . u_{3}\right)$ & $2,84^{\operatorname{tn}}$ & $<1$ & $<1$ & $3,23^{\operatorname{tn}}$ & $1,77^{\mathrm{tn}}$ & $1,04^{\text {tn }}$ & $3,56^{\mathrm{tn}}$ & $<1$ & $12,43 *$ & 4,75 \\
\hline & 7. $\left(j_{2} v s . j_{3}\right) \times\left(u_{1} v s . u_{2} u_{3}\right)$ & $<1$ & $<1$ & $<1$ & $2,03^{\text {tn }}$ & $<1$ & $6,98^{*}$ & $1,21^{\text {tn }}$ & $<1$ & $3,60^{\operatorname{tn}}$ & 4,75 \\
\hline & 8. (j2 vs. $\left.j_{3}\right) \times\left(u_{2} v s . u_{3}\right)$ & $<1$ & $<1$ & $5,67 *$ & $<1$ & $<1$ & $<1$ & $8,17^{*}$ & $<1$ & $1,49^{\text {tn }}$ & 4,75 \\
\hline & Pengaruh sederhana J & & & & & & & & & & \\
\hline \multicolumn{12}{|c|}{ C1. J pada u } \\
\hline & 9. $\mathrm{j}_{1} \mathrm{vs} . \mathrm{j}_{2} \mathrm{j}_{3}$ & $<1$ & $872,16 *$ & $<1$ & $2,52^{\text {tn }}$ & $4,29^{\text {tn }}$ & $3,73^{\operatorname{tn}}$ & $11,48^{*}$ & $1,85^{\text {tn }}$ & $491,30^{*}$ & 4,75 \\
\hline & 10. $\mathrm{j}_{2} \mathrm{vs} . \mathrm{j}_{3}$ & $1,89^{\text {tn }}$ & $2569,34 *$ & $<1$ & $41,23^{*}$ & $17,98^{*}$ & $48,45^{*}$ & $80,08 *$ & $9,39 *$ & $79,22^{*}$ & 4,75 \\
\hline \multicolumn{12}{|c|}{ C2. J pada $u_{2}$} \\
\hline & 11. $j_{1} v s . j_{2} j_{3}$ & $<1$ & $1011,50 *$ & $1,07^{\mathrm{tn}}$ & $1,97^{\mathrm{tn}}$ & $3,84^{\text {tn }}$ & $1,56^{\mathrm{tn}}$ & $13,44^{*}$ & $<1$ & $232,95^{*}$ & 4,75 \\
\hline & 12. $\mathrm{j}_{2} \mathrm{vs} . \mathrm{j}_{3}$ & $<1$ & $2545,93 *$ & $<1$ & $24,09^{*}$ & $8,62^{*}$ & $11,93^{*}$ & $31,15^{*}$ & $19,01^{*}$ & $32,63^{*}$ & 4,75 \\
\hline \multicolumn{12}{|c|}{ C3. J pada u 3} \\
\hline & 13. $\mathrm{j}_{1} \mathrm{vs} . \mathrm{j}_{2} \mathrm{j}_{3}$ & $4,42^{\operatorname{tn}}$ & $952,88^{*}$ & $<1$ & $1,30^{\text {tn }}$ & $<1$ & $<1$ & $40,11^{*}$ & $<1$ & $105,62^{*}$ & 4,75 \\
\hline & 14. $\mathrm{j}_{2} \mathrm{vs} . \mathrm{j}_{3}$ & $<1$ & $2664,05 *$ & $6,86^{*}$ & $19,79 *$ & $9,80^{*}$ & $15,97^{*}$ & $92,59 *$ & $12,50 *$ & $55,34^{*}$ & 4,75 \\
\hline & Pengaruh sederhana U & & & & & & & & & & \\
\hline \multicolumn{12}{|c|}{ D1. $U$ pada $\mathrm{j}_{1}$} \\
\hline & 15. $u_{1} v s . u_{2} u_{3}$ & $29,38^{*}$ & $1,14^{\mathrm{tn}}$ & $3,95^{\operatorname{tn}}$ & $83,95 *$ & $51,21^{*}$ & $51,90 *$ & $641,78^{*}$ & $32,67^{*}$ & $355,98^{*}$ & 4,75 \\
\hline & 16. $u_{2} v s . u_{3}$ & $25,18^{*}$ & $<1$ & $1,81^{\text {tn }}$ & $72,78^{*}$ & $34,47^{*}$ & $35,16^{*}$ & $88,93^{*}$ & $12,50 *$ & $101,93^{*}$ & 4,75 \\
\hline \multicolumn{12}{|c|}{ D2. U pada $\mathrm{j}_{2}$} \\
\hline & 17. $u_{1}$ vs. $u_{2} u_{3}$ & $45,28^{*}$ & $<1$ & $5,44^{*}$ & $44,89 *$ & $29,21^{*}$ & $15,44^{*}$ & $261,36^{*}$ & $21,41^{*}$ & $116,95^{*}$ & 4,75 \\
\hline & 18. $u_{2}$ vs. $u_{3}$ & $6,71^{*}$ & $<1$ & $8,95 *$ & $37,21^{*}$ & $18,82^{*}$ & $24,50 *$ & $83,56 *$ & $5,56^{*}$ & $24,16^{*}$ & 4,75 \\
\hline \multicolumn{12}{|c|}{ D3. U pada $\mathrm{j}_{3}$} \\
\hline & 19. $u_{1} v s . u_{2} u_{3}$ & $34,12^{*}$ & $<1$ & $5,64^{*}$ & $75,91^{*}$ & $46,21^{*}$ & $58,76^{*}$ & $314,08^{*}$ & $13,00^{*}$ & $66,09 *$ & 4,75 \\
\hline & 20. $u_{2} v s . u_{3}$ & $11,01 *$ & $<1$ & $<1$ & $43,02 *$ & $17,16 *$ & $19,43^{*}$ & $26,01^{*}$ & $10,13 *$ & $44,12 *$ & 4,75 \\
\hline
\end{tabular}

GKG = gabah kering giling: $\dagger=$ interaksi antara pengaruh utama JxU; Nilai F-hitung $<1$ tidak nyata (tn); ${ }^{*}=$ nyata menurut uji $F 5 \%$ 
Tabel 2. Persentase (kenaikan (+); penurunan (-)) hasil uji perbandingan orthogonal tinggi tanaman, laju tumbuh tanaman, nisbah pupus akar, jumlah anakan maksimum, jumlah malai, jumlah gabah per malai, persentase gabah isi, bobot 1.000 butir benih, dan hasil GKG padi yang ditanam pada berbagai cara tanam dan jumlah bibit per lubang tanam

\begin{tabular}{|c|c|c|c|c|c|c|c|c|c|}
\hline Kontras & $\begin{array}{l}\text { Tinggi Tanaman } \\
50 \text { HST }\end{array}$ & $\begin{array}{c}\text { Laju } \\
\text { Tumbuh } \\
\text { Tanaman }\end{array}$ & $\begin{array}{c}\text { Nisbah Pupus } \\
\text { Akar } 35 \text { HST }\end{array}$ & $\begin{array}{l}\text { Jumlah Anakan } \\
\text { Maksimum }\end{array}$ & $\begin{array}{l}\text { Jumlah } \\
\text { Malai }\end{array}$ & $\begin{array}{c}\text { Jumlah Gabah } \\
\text { per Malai }\end{array}$ & $\begin{array}{l}\text { Persentase } \\
\text { Gabah Isi }\end{array}$ & $\begin{array}{l}\text { Bobot } 1.000 \\
\text { ButirBenih }\end{array}$ & $\begin{array}{l}\text { Hasil Gabah } \\
\text { Kering } \\
\text { Giling }\end{array}$ \\
\hline A. Pengaruh Utama J dan U & --------- & -------------. & -----------" & -------------------. & $\%$ & $----\cdot$ & ------- & --------. & ------- \\
\hline 1. $j_{1} v s . j_{2} j_{3}$ & 0,07 & $-25,69$ & 4,00 & $-0,45$ & $-1,57$ & $-0,17$ & 0,25 & $-0,08$ & $-19,34$ \\
\hline 2. $\mathrm{j}_{2}$ vs. $\mathrm{j}_{3}$ & 0,10 & $-49,70$ & $-4,61$ & 4,52 & 4,74 & 0,93 & 1,06 & 1,09 & $-12,03$ \\
\hline 3. $u_{1}$ vs. $u_{2} u_{3}$ & 0,63 & $-0,13$ & 10,42 & $-5,72$ & $-7,14$ & $-7,14$ & $-2,21$ & $-1,19$ & $-15,75$ \\
\hline 4. $u_{2}$ vs. $u_{3}$ & $-0,44$ & $-0,45$ & 6,67 & $-5,87$ & $-6,37$ & $-0,99$ & $-1,04$ & $-0,90$ & $-11,64$ \\
\hline \multicolumn{10}{|l|}{ B1. J pada $u_{1}$} \\
\hline 5. $j_{1}$ vs. $j_{2} j_{3}$ & 0,00 & $-24,83$ & 3,09 & $-1,10$ & $-2,26$ & $-0,32$ & $-0,38$ & $-0,35$ & $-23,38$ \\
\hline 6. $j_{2}$ vs. $j_{3}$ & 0,17 & $-49,32$ & $-5,06$ & 5,34 & 5,61 & 1,35 & 1,17 & 0,91 & $-13,21$ \\
\hline \multicolumn{10}{|l|}{ B2. J pada $u_{2}$} \\
\hline 7. $j_{1} v s . j_{2} j_{3}$ & $-0,03$ & $-26,39$ & 4,67 & $-1,00$ & $-2,23$ & $-0,21$ & 0,42 & $-0,05$ & $-18,67$ \\
\hline 8. $\mathrm{j}_{2} \mathrm{vs} . \mathrm{j}_{3}$ & 0,12 & $-49,43$ & 3,79 & 4,17 & 4,02 & 0,67 & 0,74 & 1,31 & $-9,45$ \\
\hline \multicolumn{10}{|l|}{ B3. J pada $u_{3}$} \\
\hline 9. $j_{1}$ vs. $j_{2} j_{3}$ & 0,22 & $-25,84$ & 4,18 & 0,88 & $-0,09$ & 0,03 & 0,73 & 0,18 & $-14,66$ \\
\hline 10. $\mathrm{j}_{2}$ vs. $\mathrm{j}_{3}$ & 0,03 & $-50,34$ & $-11,51$ & 3,99 & 4,56 & 0,78 & 1,29 & 1,07 & $-13,40$ \\
\hline \multicolumn{10}{|l|}{ C1. U pada j1 } \\
\hline 11. $u_{1}$ vs. $u_{2} u_{3}$ & 0,57 & 0,90 & 9,47 & $-6,35$ & $-7,80$ & $-1,20$ & $-2,83$ & $-1,46$ & $-19,90$ \\
\hline 12. $u_{2}$ vs. $u_{3}$ & $-0,60$ & $-0,89$ & 7,00 & $-7,04$ & $-7,70$ & $-1,14$ & $-1,25$ & $-1,05$ & $-14,26$ \\
\hline \multicolumn{10}{|l|}{ C2. U pada $\mathrm{j}_{2}$} \\
\hline 13. $u_{1}$ vs. $u_{2} u_{3}$ & 0,71 & $-0,45$ & 10,51 & $-4,82$ & $-6,90$ & $-0,66$ & $-1,83$ & $-1,19$ & $-13,91$ \\
\hline 14. $u_{2}$ vs. $u_{3}$ & $-0,31$ & 045 & 15,15 & $-5,19$ & $-5,94$ & $-0,96$ & $-1,21$ & $-0,71$ & $-8,13$ \\
\hline \multicolumn{10}{|l|}{ C3. U pada j 3} \\
\hline 15. $u_{1}$ vs. $u_{2} u_{3}$ & 0,61 & $-1,56$ & 11,27 & $-5,95$ & $-7,38$ & $-1,27$ & $-1,98$ & $-0,92$ & $-12,05$ \\
\hline 16. $u_{2}$ vs. $u_{3}$ & $-0,41$ & $-1,35$ & $-1,82$ & $-5,36$ & $-5,45$ & $-0,85$ & $-0,67$ & $-0,94$ & $-12,14$ \\
\hline
\end{tabular}

Keterangan: $\mathrm{j}_{1}=$ Jarwo 2:1, $\mathrm{j}_{2}=$ Jarwo 4:1, $\mathrm{j}_{3}=$ Sistem tanam tegel $25 \times 25 \mathrm{~cm}, \mathrm{u}_{1}=$ jumlah bibit 1 BpLT; $\mathrm{u}_{2}=$ jumlah bibit 2 BpLT; $\mathrm{u}_{3}=\mathrm{jumlah}$ bibit 3 BpLT; B1, B2 dan $B 3$ pengaruh sederhana J pada $u_{1}, u_{2}$, dan $u_{3} ; C 1, C 2$, dan C3 pengaruh sederhana $U$ pada $j_{1}, j_{2}$, dan $j_{3}$ 
Hasil penelitian menunjukkan bahwa rumpun padi yang berada di barisan pinggir hasilnya 1,5 - 2 kali lipat lebih tinggi dibandingkan produksi rumpun padi yang berada di bagian dalam (Suharno \& Ariani, 2013).

Teknik jarwo yang diterapkan ini sangat mendukung pertumbuhan anakan padi dan jumlah malai (Tabel 1, efek interaksi tidak nyata), dilain pihak ternyata jumlah gabah per malai justu nyata berbeda pada ketiga jumlah bibit yang ditanam. Secara kualitatif hasil GKG sangat ditentukan oleh komponen hasil (Tabel 2, kontras C1, C2, dan C3) yang selaras menunjukkan dukungan terhadap hasil GKG. Selaras dengan fakta di atas, hasil penelitian Kartina et al.(2016) menyimpulkan bahwa karakter panjang malai, bobot 1.000 butir, jumlah biji, dan jumlah anakan produktif berpengaruh langsung terhadap hasil gabah. Karakter bobot 100 butir adalah karakter yang memiliki pengaruh tidak langsung paling besar melalui jumlah bulir bernas/malai terhadap bobot bulir/malai (Rohaeni \& Permadi, 2014).

Pada cara tanamjarwo 2:1, secara ratarata hasil GKG pada berbagai jumlah bibit yang ditanam lebih tinggi 55\% dan $41 \%$ daripada jarwo $4: 1$ dan tegel $25 \times 25 \mathrm{~cm}$, secara berurutan. Hal yang utama terlihat penanaman 1 BpLT lebih tinggi 43\% daripada 2 BpLT dan 3 BpLT pada jarwo 2:1 dibandingkan jarwo 4:1, sedangkan pada 2 BpLT lebih tinggi 75\% dibandingkan 3 BpLT. Hasil penelitian Kumalasari et al. (2017) menemukan bahwa terdapat interaksi yang nyata antara jumlah bibit dan jarak tanam menghasilkan bobot gabah, sedangkan Hasanuzzaman et al. (2009) hanya melaporkan bobot kering biomass padi yang dipengaruhi oleh interaksi antara jarak tanam dan jumlah bibit per lubang tanam.
Lebih lanjut Bagus et al. (2017) melaporkan, sistem jarwo 2:1 meningkatkan hasil gabah 53\% dibandingkan sistem tanam konvensional/ tegel, selain itu penanaman 1 BpLT meningkatkan hasil gabah $17 \%$ dan $10 \%$ dibandingkan penanaman $2 \mathrm{BpLT}$ dan 3 BpLT.

Tabel 1 memperlihatkan bahwa komponen hasil (jumlah malai dan bobot 1.000 butir benih) nyata dipengaruhi oleh perbedaan jumlah bibit per lubang tanam. Jumlah malai dengan jumlah bibit $1 \mathrm{BpLT}$ lebih tinggi 7,14\% daripada 2 BpLT dan 3 BpLT, konsistensinya searah dengan semakin sedikitnya jumlah bibit per lubang tanam (2 BpLT lebih tinggi 6,37\% daripada 3 $B p L T)$. Fakta ini sangat mendukung hasil GKG, karena jumlah malai merupakan penentu banyaknya jumlah gabah per malai. Menurut Kartina et al. (2016), karakter jumlah anakan produktif dan jumlah gabah total memiliki pengaruh langsung dan positif terhadap hasil gabah dengan koefisien lintasan sebesar 0,40 dan 0,21 . Sedangkan bobot 1.000 butir gabah isi menunjukkan kenaikan yang sangat kecil sekitar $1 \%$, tentunya nilai ini kurang bermakna meskipun secara statistika nyata berbeda. Hal ini tentunya berkaitan dengan sifat benih padi yang ditunjukkan bobot 1.000 butir gabah isi yang sangat ditentukan oleh sifat genetisnya.

Laju tumbuh tanaman sepuluh harian (25 - 35 HST) nyata dipengaruhi oleh cara tanam, sedangkan peubah lainnya pengaruhnya tidak nyata (tinggi tanaman, NPA 35 dan laju asimilasi bersih (LAB 25-35 HST dan NPA 25 data tidak ditampilkan). Laju tumbuh tanaman sangat berkaitan erat dengan hasil fotosintat yang dihasilkan selama periode tertentu. Laju tumbuh tanaman padi hibrida Mapan P-05 yang ditanam secara jarwo 2:1 lebih tinggi $26 \%$ 
dibandingkan dengan penanaman jarwo 4:1 dan tegel $25 \times 25 \mathrm{~cm}$, bahkan dengan jarwo 4:1 lebih tinggi $50 \%$ daripada tegel $25 \times 25$ $\mathrm{cm}$. Temuan ini sangat berkaitan dengan cara tanam jarwo yang mampu menghasilkan fotosintat yang besar pada periode antara 25 HST dan 35 HST, dan pada akhirnya terjadi kenaikan hasil GKG (jika efek utama yang dilihat) sebesar rata-rata lebih dari $30 \%$. Seperti yang dijelaskan lebih awal bahwa sistem jarwo mampu memberikan jarak yang longgar (legowo = bahasa Jawa), tanaman lebih banyak menerima cahaya matahari dan udara.

Secara umum hasil penelitian ini menunjukkan bahwa hasil GKG masih lebih rendah dibandingkan potensi hasil dari deskripsi padi hibrida Mapan 05, yaitu sebesar 7,79 $\mathrm{t} \mathrm{ha}^{-1}$. Fakta ini didukung oleh rendahnya bobot 1.000 butir gabah isi yang berkisar antara 28,13 - 28,83 g (deskripsi $30,70 \mathrm{~g}$ ), meskipun jumlah anakan produktif dan jumlah gabah per malai lebih tinggi dibandingkan deskripsi, yaitu masingmasing $21-24$ batang vs. $7-19$ batang dan $198-203$ butir vs. 169 butir. Selain itu yang menyebabkan hasil GKG rendah, karena pada saat penelitian diperoleh persentase biji isi/bernas sekitar $77,76 \%$ - 80,62 \%. Hal ini karena terjadinya serangan hama walang sangit yang menghisap biji saat masak susu (pada saat penelitian berlangsung, banyak petani tidak menanam padi karena memasuki musim kemarau).

\section{SIMPULAN}

1) Sistem tanam jarwo $2: 1$ dan jarwo $4: 1$ meningkatkan pertumbuhan padi dibandingkan sistem tanam tegel $25 \times 25$ $\mathrm{cm}$.

2) Penanamnan 1 BpLT menghasilkan komponen hasil dan hasil GKG lebih tinggi dibandingkan penanaman 2 dan 3 BpLT.

3) Penanaman $1 \mathrm{BpLT}$ dengan sistem jarwo 2:1 memberikan hasil GKG $\left(6,86 \mathrm{t} \mathrm{ha}^{-1}\right)$ lebih tinggi $22 \%$ dan $40 \%$ dibandingkan dengan penanaman $2 \mathrm{BpLT}\left(5,64 \mathrm{t} \mathrm{ha}^{-1}\right)$ dan $3 \mathrm{BpLT}\left(4,59 \mathrm{t} \mathrm{ha}^{-1}\right)$, baik yang ditanam pada sistem tanam jarwo 4:1 dan sistem tegel $25 \times 25 \mathrm{~cm}$.

\section{DAFTAR PUSTAKA}

Ali, M., Hosir, A., \& Nurlina, N. (2017). Perbedaaan Jumlah Bibit per Lubang Tanam Terhadap Pertumbuhan dan Hasil Tanaman Padi (Oryza sativa L.) dengan Menggunakan Metode SRI. Gontor AGROTECH Science Journal, 3(1), https://doi.org/10.21111/agrotech.v3 i1.898

Arnama, I. N. (2020). Pertumbuhan Dan Produksi Varietas Padi Sawah (Oryza sativa L.) Dengan Variasi Jumah Bibit Per Rumpun. Jurnal Pertanian Berkelanjutan, 8(2), 166-175. https://dx.doi.org/10.30605/perbal.v $8 i 3.1546$

Bagus, M., Nararya, A., Santoso, M., \& Mei, F. (2017). Kajian Beberapa Sistem Tanam dan Jumlah Bibit Per Lubang Tanam Pada Produksi Padi (Oryza sativa L.) var . INPARI 30. Jurnal Produksi Tanaman, 5(8), 1338-1345.

Dani, U. (2018). Pengaruh Kombinasi Asam Humat, Jarak Tanam Dan Jumlah Bibit Per Lubang Tanam Terhadap Pertumbuhan Dan Hasil Tanaman Padi (Oryza sativa L. 'PANDAN PUTERI' ). Jurnal Ilmu Pertanian Dan Peternakan, 6(1), 8-19. http://www.jurnal.unma.ac.id/index. php/AG/article/download/880/861 
Donggulo, C. V, Lapanjang, I. M., \& Made, U. (2017). Pertumbuhan dan Hasil Tanaman Padi (Oryza sativa L.) Pada Berbagai Pola Jajar Legowo dan Jarak Tanam. J. Agroland, 24(1), 27-35. http://jurnal.untad.ac.id/jurnal/index. php/AGROLAND/article/viewFile/856 9/6801

Hasanuzzaman, M., Nahar, K., Roy, T. S., Rahman, M. L., Hossain, M. Z., \& Ahmed, J. U. (2009). Tiller Dynamics and Dry Matter Production of Transplanted Rice as Affected by Plant Spacing and Number of Seedling per Hill. Academic Journal of Plant Sciences, 2(3), 162-168.

Ikhwani, Pratiwi, G. R., Paturrohman, E., \& Makarim, A. K. (2015). Peningkatan Produktivitas Padi Melalui Penerapan Jarak Tanam Jajar Legowo. Iptek Tanaman Pangan, 8(2), 72-79.

Kartina, N., Wibowo, B. P., Widyastuti, Y., Rumanti, I. A., \& Satoto, . (2016). Correlation and Path Analysis for Agronomic Traits in Hybrid Rice. Jurnal IImu Pertanian Indonesia, 21(2), 7683.

https://doi.org/10.18343/jipi.21.2.76

Kumalasari, S. N., Sudiarso, \& Suryanto, A. (2017). Pengaruh Jarak Tanam dan Jumlah Bibit Pada Tanaman Padi (Oryza sativa L.) Hibrida Varietas PP3. Jurnal Produksi Tanaman, 5(7), 12201227.

http://protan.studentjournal.ub.ac.id /index.php/protan/article/view/497/ 500

Misran. (2014). Efisiensi Penggunaan Jumlah Bibit Terhadap Pertumbuhan dan Produksi Padi Sawah. Pertanian Terapan, 14(1), 39-43. https://doi.org/10.25181/jppt.v14i1.1 40

Muyassir. (2012). Efek Jarak Tanam, Umur dan Jumlah Bibit Terhadap Hasil Padi Sawah (Oryza sativa L.). Jurnal Manajemen Sumberdaya Lahan, 1(2), 207-212. http://erepository.unsyiah.ac.id/MSDL/article /view/2190/2146

Rohaeni, W. R., \& Permadi, D. A. N. K. (2014). Analisis Sidik Lintas Beberapa Karakter Komponen Hasil Terhadap Daya Hasil Padi Sawah Pada Aplikasi Agrisimba. Agrotrop: Journal on Agriculture Science, 2(2), 185-190.

Safitri, D. A., \& Suminarti, N. E. (2018). Pengaruh Sistem Tanam Dan Jumlah Bibit Per Lubang Tanam Pada Pertumbuhan Dan Hasil Tanaman Padi (Oryza sativa L .). 6(8), 1728-1737. http://protan.studentjournal.ub.ac.id /index.php/protan/article/download/ 834/857

Sari, D. N., Sumardi, S., \& Suprijono, E. (2014). Pengujian Berbagai Tipe Tanam Jajar Legowo terhadap Hasil Padi Sawah. Akta Agrosia, 17(2), 115124.

https://doi.org/10.31186/aa.17.2.115 $-124$

Simangunsong, E. R. A., Harahap, E. M., \& Lubis, A. (2018). Pengaruh Jumlah Bibit dan Modifikasi Sistem Tanam Jajar Legowo Terhadap Pertumbuhan dan Produksi Padi Sawah (Oryza sativa L.) Di Desa Tanjung Mulia Kecamatan Tanjung Morawa Kabupaten Deli Serdang. Jurnal Pertanian Tropik, 5(2), 292-300. https://doi.org/https://doi.org/10.32 734/jpt.v5i2.3023

Stoop, W. A., Uphoff, N., \& Kassam, A. (2002). A review of agricultural research issues raised by the system of rice intensification (SRI) from Madagascar: opportunities for improving farming systems for resource-poor farmers. Agricultural 
Systems, $\quad 71(3), \quad 249-274$. https://doi.org/https://doi.org/10.10 16/s0308-521x(01)00070-1

Suharno, \& Ariani, K. T. (2013). Pengaruh jumlah bibit pada berbagai sistem tajarwo terhadap peningkatan produktivitas padi (Oryza sativa L.). Jurnal IImu-IImu Pertanian, 7(1), 3542.

Susilo, J., Ardian, \& Ariani, E. (2015). Pengaruh Jumlah Bibit Per Lubang Tanam Dan Dosis Pupuk N, P Dan K Terhadap Pertumbuhan Dan Produksi Padi Sawah (Oryza sativa L .) Dengan Metode SRI. Jom Faperta Vol., 2(1), 13. https://media.neliti.com

Suyamto (Ketua). (2007). Petujuk Teknis Lapangan Pengelolaan Tanaman Terpada (PTT) Padi Sawah Irigasi. Balai Penelitian dan Pengembangan Pertanian, Kementerian Pertanian.

Thakur, A. K., Uphoff, N., \& Antony, E. (2010). An assessment of physiological effects of system of rice intensification (SRI) practices compared with recommended rice cultivation practices in India. Experimental
Agriculture, 46(1), 77-98.

Uphoff, N. (2003). Higher yields with fewer external inputs? The system of rice intensification and potential contributions to agricultural sustainability. International Journal of Agricultural Sustainability, 1(1), 3850.

https://doi.org/10.3763/ijas.2003.010 5

Wangiyana, Z. L. dan S., Sri, B., Of, S., Intensification, R., \& Berbagai, P. (2009). Pertumbuhan dan Hasil Tanaman Padi Varietas Ciherang dengan Teknik Budidaya "Sri (System Of Rice Intensification)" pada Berbagai Umur dan Jumlah Bibit Per Lubang Tanam. Crop Agro, 2(1), 70-78. https://cropagro.unram.ac.id/index.p hp/caj/article/view/37/28

Widyastuti, Y., Rumanti, I. A., \& Satoto. (2015). Perilaku Pembungaan Galurgalur Tetua Padi Hibrida. Iptek Tanaman Pangan, 7(2), 67-78.

Yoshida, S. (1981). Fundamentals of rice crop science. Int. Rice Res. Inst. 